\title{
PECULIARITIES OF THE PHENOMENON OF EMOTIONAL BURNOUT SYNDROME AMONG EMPLOYEES OF THE NATIONAL POLICE OF UKRAINE
}

\author{
Kisil Z. R.
}

\section{INTRODUCTION}

Professional activities of National Police employees are always accompanied with considerable psycho-emotional stress, professional stress and risk, psychological traumatism. The stressful nature of the work of the National Police officers, as well as the negative determinants of professional activity, occasionally lead to the emergence of a negative phenomenon - emotional burnout, and the consequence of their activity under conditions of constant influence of stress factors is the loss of positive professional motivation, manifestation of various neurotic reactions, mental and physical health disorders. Most scientists-police officers are inclined to believe that $70 \%$ of police officers who have used guns during the fulfillment of their official duties take the decision to quit from service for five years because they have experienced a significant mental injury. Research of this category of persons revealed that they had post-traumatic stress disorder $(60 \%)$, and every third police officer had excessive emotional and psychological stress (36\%), functional impairment $(49.7 \%)^{1}$.

Special conditions of professional activity of the employees of the National Police of Ukraine, namely: risk-taking activity with unpredictable consequences (injury, wounds), communication with antisocial elements, permanent mental and physical overload - lead to intensive and large-scale development of emotional burnout, and therefore to professional deformation. The activities of the police are characterized by a significant negative emotional saturation, when during their professional duties it is necessary to restrain their negative emotions, and emotional unloading is mostly postponed for an indefinite period of time. The emotional burnout, according to most scholars, is defined as "... the acquired stereotype of emotional response most often within the limits of professional behavior. On the one hand, it allows a person to dose and economically use energy resources, and on the other hand - it can negatively influence the performance of his professional activities, relations with partners in the sphere of communication and service", 2 .

1 3.Р. Кісіль, В.В. Середа. Юридико-психологічні засади запобігання професійній деформації працівників правоохоронних органів. Львів: ЛьвДУВС, 2016. 847 с.

${ }_{2}$ С.Д. Максименко, В.С. Медвєдєв. Юридична психологія: особистісно-діяльнісний підхід. К.: Слово, 2017. 405 с. 
Researching the phenomenon of emotional burnout among police officers, scientists-policemen came to the conclusion that this phenomenon is, so to speak, "infectious", since most of the policemen who are prone to this syndrome eventually become misanthropic, negativist, and despondent to their own success. Being in constant interaction with colleagues, who are also under the influence of stress factors, they can turn them into a group of "burning out".

It is clear that the emotional burnout syndrome arises as a result of accumulation of negative emotions over many years, the performance of official functions under conditions of uncertainty, risk and stress, and as a rule, leads to psychological and emotional exhaustion of an employee. We believe that the empirical study of the phenomenon of emotional burnout among the employees of the National Police of Ukraine is extremely relevant, since psycho-emotional well-being of law enforcement officers is one of the main determinants of the quality and efficiency of their professional activities.

Despite the considerable scientific interest in the "emotional burnout" syndrome of law enforcement officers that is primarily due to the pragmatic problem of improving the effectiveness of the Ministry of Internal Affairs of Ukraine unfortunately, it was not given proper attention. The thorough scientific and theoretical basis in our study of the "emotional burnout" syndrome is grounded on the position, scientific ideas, doctrinal positions set forth in scientific research by both foreign and national scholars - Kh. Aliyev, M. Burysh, A. Vydaya, M. Ginzburg, S. Gramling, G. Greenberg, G. Dion, F. Jones, M. Dmytrieva, L. Kytayev-Smyk, N. Levytska, G. Lozhkina, M. Leiter, D. Lewis, S. Maksymenko, L. Maltsa, E. Makhera, V. Nikonova, G. Nykiforova, V. Orla, M. Smulson, V. Snetkov, T. Formanyuk, $\mathrm{H}$. Freidenberger, as well as questions of the methodology of its diagnostics (they were studied, in particular, by V. Boiko, N. Vodopianova, S. Jackson, K. Maslach, T. Ronginskaya, O. Starchenko and others).

Thus, recalling the structure and content of the syndrome of "emotional burnout," we will focus on the scientific researches of K. Maslach, S. Jackson, V. Shaupheli, T. Formaniuk, V. Boiko, L. Karamushka, N. Nazaruk. Considering all manifestations of the syndrome of "professional burnout" through the prism of various indirect determinants, we summed up the findings of famous scientists in the field of legal psychology, among them: S. Beznosov, A. Budanov, L. Vasiliev, I. Vashchenko, A. Dulov, K. Zlokazov, L. Kolodkin, V. Kolomiets, H. Langerok, K. Leonhard, I. Maksymov, V. Medvedev, N. Mityurina, M. Monakhova, S. Rainkin, A. Ratinov, V. Robozerov, A. Rosh, G. Ryabov, L. Ternovsky, V. Samarin, A. Svencytsky, Yu. Strigunenko and others. With regard to the determinants of the emergence of the "emotional burnout" syndrome, the main empirical 
data was based on the work of V. Orel, T. Zaichikova, K. Malysheva, $\mathrm{N}$. Bulatevich. In the study of the development of algorithm of methods and means of prevention and correction of the consequences of the syndrome of "emotional burnout," we will turn to the scientific researche of I. Ostopoltsiy, I. Sergeyev, L. Karamushka, T. Zaychikova, N. Nazaruk. Regarding the peculiarities and specifics of the study of the syndrome of "professional burnout" of the workers of the law enforcement agencies, we take into account the scientific works of S. Beznosov, S. Borisov, A. Budanov, S. Vyshnichenko, Z. Kisil, A. Krapivin, B. Medvedev, A. Molchanov, B. Novikov, Y. Potapchuk, O. Timchenko, O. Khairulina.

The purpose of the article is to reveal the psychological peculiarities of the emotional burnout syndrome of the personnel of the National Police of Ukraine (on the example of the study of employees of the National Police of Ukraine).

\section{Tasks:}

1) to characterize the determinants of the "emotional burnout" syndrome among the employees of the National Police of Ukraine;

2) to clarify the meaning of the concept of "emotional burnout" syndrome, taking into account the professional scope of the activities of the staff of the National Police of Ukraine;

3 ) to diagnose the level of formation of the syndrome of "emotional burnout" among the employees of the National Police of Ukraine;

4) to determine the effect of the "emotional burnout" syndrome on the results of the professional activity of the National Police employees of Ukraine.

\section{Methods of research.}

To accomplish our research objectives, we have applied a whole range of methods and techniques of cognition that are caused by the peculiarities of the syndrome of "emotional burnout" and the specifics of the professional environment of the police officer. Taking into account the fact that the "emotional burnout" syndrome of the workers of the National Police of Ukraine is manifested as a complex and multifunctional phenomenon, the reliability of its study is directly proportional to the methods that will be used. In order to obtain the most objective results, a systematic approach, based on the interdisciplinary implementation of general scientific, special-scientific and concrete scientific methods of cognition, has been applied. Thus, the complex application of the mechanism of the theory of normative description of the activities of the staff of the National Police of Ukraine, the fundamental doctrinal provisions of the psychological theory of personality, the theoretical foundations of legal deontology will help to comprehensively clarify the 
essence of the syndrome of "emotional burnout", its dynamics, determinants of occurrence and basic manifestations.

The application of the methodology of structural functionalism allowed to isolate the law-enforcement sphere as a component of the socio-cultural field and, based on the analysis of its functions in this system, to consider the environment of the police as a phenomenon that has a systemic structure, and in the study of the syndrome of "emotional burnout," this allowed to reveal not only the structure of its internal mechanism and the action of its individual determinants, but also their interconnection at different levels. Application of this approach contributed to the study of substantive content and organizational "multilayer" syndrome of "emotional burnout", a thorough dialectical relationship of its determinants in the structure of a complex holistic organism.

The synergetic method was also actively used, since this approach involves understanding the phenomenon under research, which has a nonlinear causal nature, taking into account the logic of the effect of random fluctuation. A policeman as a social subject (with all the set of rights, duties, professional settings and, at the same time, personal interests and mental properties) is a non-linear open system that constantly interacts with the environment, taking from the last information, treating it and dictating the results of such a study with the hope that this environment will understand and fulfill its orders.

Concrete scientific methods necessary for the study of the "emotional burnout" syndrome among the workers of the National Police of Ukraine, were distinguished as follows: 1) "diagnostics of the level of emotional burnout" (V. Boiko); 2) "determination of mental burnout" (O. Rukavishnikov); 3) the methodology of K. Maslach and S. Jackson; 4) the method of "burnout" syndrome in the professions of the "man-man" system (G. Nikiforov); 5) a method of "evaluating personal burning potential" (J. Gibson); 6) the method of "studying the" burnout syndrome"(J. Greenberg); 7) multi-factor personal questionnaire by R. Kettella (No. 105), (16PF - questionnaire). The above methods primarily aim at finding out the determinants and stages of the "emotional burnout" of a policeman; study of the syndrome of "emotional burnout" in the professions of the "man-man" system; study of the main manifestations of emotional burnout among the policeman on the interpersonal, personal and motivational levels.

In addition to these techniques, empirical methods for collecting information, such as surveillance and diagnostics, were used, which, in turn, are used by means of questioning, questionnaires, and testing.

Officers of the security police (35 people), special police (29 people), patrol police (38 people) and criminal police (43 people), including 17 females, 128 - males took part in the empirical study. The respondents under 
study were aged from 20 to 30 years old, service life at the time of the study was: up to three years -59 people, from 4 to 5 years -86 people.

\section{Results and discussions.}

The syndrome of "emotional burnout" should not be considered as a phenomenon of the present, because this phenomenon always existed in various forms, determined by different conditions. For the first time, the term "burnout" ("emotional burnout") was used in 1974 to describe the psychological state of exhaustion, its own uselessness in the professions of the "man-man" system, by the American psychiatrist H. Freidenberger.

Despite the long history of continuous attempts to explore the syndrome of "emotional burnout" as a complex psychological phenomenon, in the scientific literature there are conceptual differences in the concept itself, this phenomenon still remains the subject of scientific and practical interest. Currently, most scientists consider the emotional burnout as "... the result of the influence of a complex of stress factors"3. V. Boiko regards emotional burnout as " $\ldots$ the developed mechanism of psychological protection in the form of total or partial exclusion of emotions (reduction of their energy), which is a reaction of a person to certain psycho-traumatic influences, that is, it refers to the acquired stereotype of emotional, most often emotional behavior" ". T. Zaichikova believe that "... continuous or progressive imbalance in conditions of intense activity inevitably leads to professional burnout as a consequence of uncontrolled stress" ${ }^{\text {. }}$.

Thus, in the opinion of K. Maslach, H. Freidenberger "emotional extinction" is interpreted as "... a state of physical, mental and emotional exhaustion caused by long-term stay in emotionally overburdened situations of communication"6. M. Salanova, V. Shaupheli and others believe that "emotional burnout" is "... a two-dimensional model consisting, firstly, of emotional exhaustion and, secondly, of depersonalization, that is, the deterioration of the attitude towards others, and sometimes to himself ${ }^{7}$. V. Boiko, K. Maslach, R. Burke, T. Formaniuk and others note that this

3 Орел В.Е. Исследование феномена психического выгорания в отечественной и зарубежной психологии // Проблемы общей и организационной психологии. Ярославль, 1999. С. 76-97.

4 Бойко В.В. Синдром “эмоционального выгорания” в профессиональном общении. 2-е изд. СПб.: Сударыня, 2001. 434 с.

5 Технології роботи організаційних психологів / За наук. ред. Л.М. Карамушки. К.: Фірма “ІНКОС", 2005. 366 c.

6 Maslach, C., Goldberg, J. Prevention of burnout: New perspectives // Applied and Preventive Psychology, 1998, V.7, pp. 63-74.

${ }^{7}$ Schaufeli, W.B., Salanova, M., Gonzalez-Roma, V. and Bakker, A.B. The measurement of engagement and burnout and A confirmative analytic approach // Journal of Happiness Studies, 2003, V. 3, pp. 71-92. 
phenomenon should be regarded as “... a three-component system consisting of emotional exhaustion, depersonalization and reduction of personal personality achievements" $", 9,10,11,12$. N. Vodopianova emphasizes that “... professional destruction of the person, which manifests itself in the form of persistent mental experiences, as well as changes in the quality, structure and content of professional activity..." ${ }^{\prime 13}$.

A number of other scientists in their scientific research have proved that “... in the case of insufficiency of indicators of professional reliability of the subject of professional activity, incompleteness of his mental regulation, exceeding the stress factors of the threshold of his stress resistance, the duration of such influence, the qualitative characteristics of personal professional reliability and disability can be deteriorated and are transformed to a level of personal deformation, first of all - professional burnout"14.

Professional activities of police officers are always accompanied by extreme and risky situations. Scientific inquiries from foreign authors give grounds for arguing that extremely difficult conditions for the activities of police officers sometimes lead to violations of mental activity, the emergence of post-traumatic stress disorder, sometimes unjustified aggressiveness, predisposition to unlawful behavior, manifestations of professional deformation. Taking into account the destructive effect of emotional burnout on the personality and professional activity of the staff of the National Police of Ukraine, we have analyzed the scientific developments of foreign scientists and practitioners regarding the identification of extreme and stressful situations that arise when performing professional tasks by the police of the UK, the United States police, the United Nation Civilian Police, and Germany.

G. Gudyonson, R. Adlam cite a table of 45 stress factors that arise in the professional activities of the UK policemen. So, in their opinion, the dominant stresses include: the seizure of hostages by terrorists; release of hostages;

${ }^{8}$ Бойко В.В. Синдром “эмоционального выгорания” в профессиональном общении. 2-е изд. СПб.: Сударыня, 2001. 434 с.

${ }^{9}$ Maslach C.M. Job burnout: new directions in research and intervention // Current Directions in Psychological Science, 2003, V. 12, pp. 189-192.

${ }^{10}$ Burke, R.J., Greengalass, E. A longitudinal study of psychological burnout in teachers // Human Relations, 2003, V. 48 (2), pp. 187-202.

${ }^{11}$ Maslach, C., Leiter, M.P. The truth about burnout: How organization cause personal stress and what do about it. San Francisco, CA: Jossey-Bass, 1997. 197 p.

12 Форманюк Т.В. Синдром “эмоционального сгорания” как показатель профессиональной дезадаптации учителя // Вопросы психологии. 1994. № 6. С. 57-63.

13 Водопьянова Н.Е., Старченкова Е.С. Синдром выгорания: диагностика и профилактика. 2-е изд. СПб.: Питер, 2008. 336 с.

${ }^{14}$ Maslach, C., Schaufeli, W.B., Leiter, M.P. Job Burnout // II Annual Review of Psychology, 2001, V. 52, pp. 397-422. 
confrontation with an armed criminal; dangerous confrontation with the objects of professional activity; the end of the riots; uncertainty in supporting the partner; committing acts that are outside the legal field, etc. ${ }^{15,16}$

J. Cueil gave a table of stress potential (144 situations) which may occur to a US police officer. So, according to the US police, the most extreme situations include: the death of a partner while performing professional duties; colleague's suicide; the use of weapons for killing; murder committed by a policeman; getting injured or wounded while performing their duties, etc. ${ }^{17}$

O. Telichkin distinguishes between 50 situations that are the most stressful during the service of the UN Civilian Police. So, of the 15 situations noted by the author, seven are related to the security issue; five - to the problems of relations with colleagues; three - to the intimate-personal sphere. Often, among the personnel of the UN Civilian Police there are the following stressful situations, namely: the seizure of hostages by terrorists; death, injury of colleagues; situations of uncertain nature; antisocial behavior of colleagues; local residents' attack on unit employees ${ }^{18}$.

G. Litvinova, investigating the socio-psychological support of police in Bavaria, highlighted the most stressful situations which police officers often face, namely: the death of a colleague; getting injuries while performing professional tasks; release of hostages; counteracting criminals; carrying out professional activities in case of uncertainty and risk to life; colleague's suicide; maintaining law and order in times of unrest; application of measures of physical coercion or special means or weapons for killing, etc. ${ }^{19}$

According to the results of our survey, the most typical extreme and stressful situations that are often encountered by workers of the National Police of Ukraine are identified. Criminal police officers often encounter the following stressful situations, namely: communication with representatives of the criminal subculture; the need to handle a large number of cases; conflict, and sometimes aggressive communication with recidivists; conflict communication in the field of professional activity; chronic fatigue and exhaustion; lack of time for the family. Police officers often encounter the

${ }^{15}$ Seligman, M., Csikszentmihalyi, M. Positive Psychology: An introduction // American Psychologist, 2014, V. 55, pp. 5-14.

${ }^{16}$ Kurtz, D. Burnout Among Police Officers: Differences In How Male, Female Police Officers Manage Stress May Accentuate Stress On The Job // American J. of Criminal Justice, 2008, V. 2, pp. 17-26.

17 Свон Р.Д. Эффективность правоохранительной деятельности и ее кадровое обеспечение в США и России. СПб. : Алетейя, 2000. 296 с.

${ }^{18}$ Покровский Н.В. Организация психологической поддержки персонала полиции за рубежом. Режим доступу https://psyinst.moscow/biblioteka/part=articleid=1734

19 Литвинова Г.А. Социально-психологическое обеспечение деятельности полиции Баварии (Германия) // Юридическая психология. 2010. № 3. С. 32-36. 
following stressful situations: long-term communication with antisocial elements and inadequate people; communication with aggressive citizens during mass events; application of measures of physical coercion, special means and weapons for killing; the need to take decision independently in case of the absence of information and time; low level of cohesion in the group. For employees of the security police, special police and police of special purposes, the following situations are of a stressful nature, namely: death of colleagues; getting injured or wounded; application of measures of physical coercion, special means and weapons for killing; detention of criminals; long-term communication with inadequate citizens; processing at the same time considerable amount of information; chronic fatigue and exhaustion; communication with convicted or recidivists; sometimes conflict communication with direct managers in the field of professional activity; low level of cohesiveness in the group; observation of human losses; lack of time to take a decision. Thus, according to the results of the survey, the activities of the National Police staff of Ukraine on the level of extremism should be built in the following sequence: security police, special police and police of special purposes -9 points; patrol police -8 points; criminal police $-7-8$ points.

Therefore, based on the objectives of the study, analysis of scientific research, we can formulate preliminary generalizations: firstly, the content and conditions for the professional activities of police officers, especially the tasks assigned to them, determine the nature of the functional state of the body of the law enforcement officer and, as a consequence, the effectiveness of professional activity; secondly, a significant level of stress factors, their excessive influence and duration can cause emotional burnout, including professional deformation; third, emotional burnout is primarily a dynamic process, which arises as a result of prolonged stress in the absence of control by the policeman of his own functional state; fourth, the emergence and development of emotional burnout is caused by a set of interconnected determinants, namely: professional, organizational and personal, which are directly related to the specifics of law enforcement activities.

After analyzing various approaches, the notion of "emotional burnout of the employee of the National Police of Ukraine" should be considered as a reproduction of a state of physical or psycho-emotional exhaustion suffered by a police officer due to the long-term inclusion into a mediumintensity psychological trauma. Therefore, we conducted research based on the stages of the formation and manifestation of the syndrome of "emotional burnout of a police officer" by finding out the determinants of its occurrence.

For singling out the main determinants of the emergence of the "emotional burnout" syndrome among the National Police officers, a valid methodology 
by V. Boiko was used. Thus, the respondents were asked to answer 84 questions that reveal the features of one of the three components of the "emotional burnout" syndrome, namely:

1) stress - manifested in a constant sense of chronic fatigue, emotional exhaustion, dissatisfaction with the professional activity performed, the dynamic development of anxiety and depression;

2) resistivity - characterized by excessive emotional exhaustion, manifested in an inadequate situation in an emotional response, emotional and moral disorientation, and sometimes reduction (simplification) of professional duties;

3) exhaustion - characterized by a state of mental, emotional exhaustion (devastation), leveling of personal achievements in professional activity, the dynamic development of psychosomatic and psycho-vegetative diseases.

As a result of the analysis of respondents' responses, the following results were obtained (see Figures 1-3).

Thus, the phase of resistance is characterized by a sufficient level of formation (the stage of formation is $51,4 \%$, the developed stage is $14,2 \%$ ) (see Diagram 1), which accompanies a kind of psychological resistance and blocking of memories from conscious memory; more than half of our respondents are presented as individuals who are at the stage of the formation of resistance.

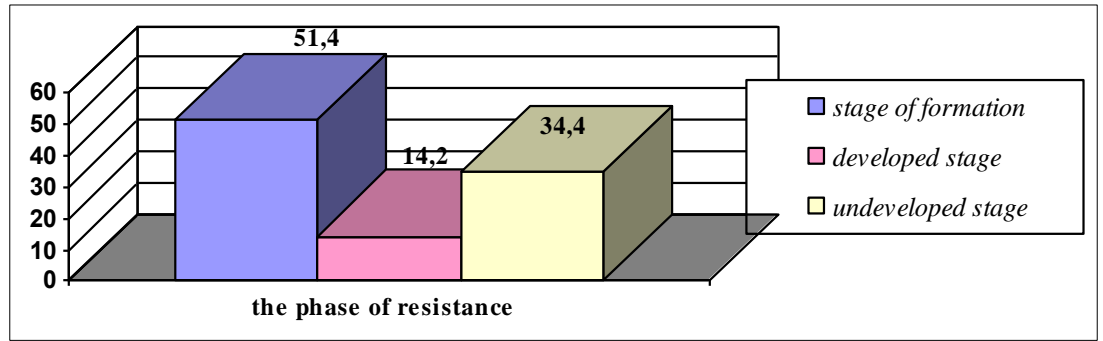

Diag. 1. Indicators of the formation of the resistance phase

$11 \%$ of respondents are characterized by a high rate of development of the first component - "stress" (see Diagram 2), internal emotional sense of discomfort. At the same time, the majority of respondents are just at the stage of unformed anxiety (apparently, given to the insignificant period of work in police system).

$6 \%$ of respondents are distinguished by a high level of the third component "exhaustion" (see Diagram 3). And in this case even more respondents appeared on the unformed stage of professional fatigue, which may be due to their physiological youth or age. 


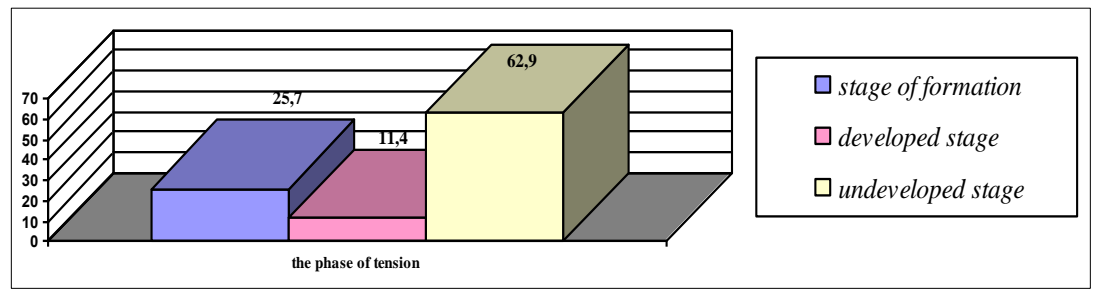

Diag. 2. Indicators of the formation of the tension phase

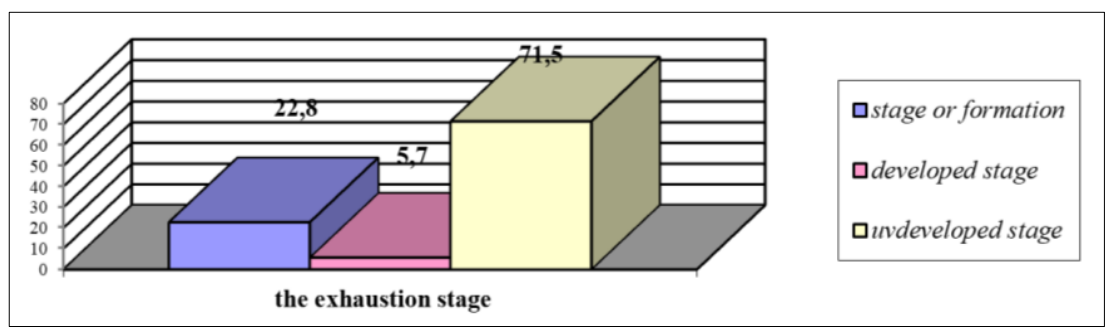

\section{Diag. 3. Indicators of the formation of the exhaustion phase}

The analysis of the results suggests that the development of "emotional burnout" syndrome among police officers is manifested through the domination of the second component - "resistance": the "emotional burnout" syndrome is not formed among $67 \%$ of respondents, $24 \%$ are at the stage of formation; and for $9 \%$ of policemen it has already been formed. So, almost a tenth of young and potential police professionals could not develop the stability of their psyche to influence of environment, the ability to resist negative factors, to form a kind of social resistance.

To diagnose the manifestation of the "burnout" syndrome on the three main levels (interpersonal, personal, and motivational), the method "determining mental "burnout" was used (O. Rukavishnikova). This methodology contains of 72 positions regarding the senses associated with work, which correspond to three scales: 1) psycho-emotional exhaustion, 2) personal separation, and 3) professional motivation. The results of the research according to O. Rukavishnikov's method showed that $62 \%$ of the respondents had the third component - "professional motivation", which suggests that the development of mental burnout is at a level slightly higher than the average.

In order to study the tendencies of negative attitude towards himself as a professional, leveling of professional achievements and self-esteem by the police officers, the method "burnout syndrome in the system of professions 
"a man-a man" was used, which provides answers to 22 questions, which, in turn, are systematized according to three subscales: 1) emotional exhaustion; 2) depersonalization; 3 ) reduction of personal achievements. The survey showed that $56 \%$ of the respondents are characterized by the domination of the third component - "reduction of personal achievements"; $30 \%$ are characterized by the domination of the second component - "depersonalization"; $14 \%$ confirmed the presence of the first component - "emotional exhaustion". The obtained results of the survey indicate that among respondets there are tendencies to negative self-assessment of personal capabilities and leveling out the results of their professional activity, deformation of relations with their colleagues and with the objects of professional activity, which can be presented in frank manifestations of cynicism.

After statistical processing of the results of the correlation analysis according to Pearson's criterion we established certain regular relationships between emotional burnout by the method of V. Boiko and individualpersonal qualities by R. Kettel, namely:

1) the inversely proportional relationship between the stress phase and courage $(r=-0.419$ at $p<0.05)$, which gives grounds for asserting the desire of the police to "stay in the shadows", and tension and uncertainty in their actions in risky situations;

2) inversely proportional relationship between the resistance phase and self-control $(\mathrm{r}=-0.352$, at $\mathrm{p}<0.05)$ and courage $(\mathrm{r}=-0.470$ at $\mathrm{p}<0.01)$, which indicates that the police who are in a state of resistance sometimes do not control their actions, violate discipline, allow manifestations of arbitrariness, are easily subjected to panic, they have intrinsic signs of internal conflict;

3 ) is directly proportional to the relationship between the resistive phase and the internal stress $(r=0.334$ at $\mathrm{p}<0.05)$, which shows signs of anxiety, tension and sometimes even irritability among those who are emotionally exhausted;

4) inversely proportional relationship between the exhaustion phase and courage $(r=-0.418$, with $p<0.05)$ and openness $(r=-0.400$ at $p<0.05)$; these results confirm the assumption that respondents who experience a state of emotional exhaustion, are characterized by indecisiveness, isolation, lack of flexibility in communicating with different categories of citizens.

In the process of correlation analysis, applied to the information obtained by A. Rukavishnikov's method and the multifactor personal questionnaire by R. Kettel, we established:

1) the inversely proportional relationship between the scale of "personal separation" and courage $(r=-0,374$ at $p<0,05)$, indicating that the surveyed respondents to a certain extent are socially unadapted, they have a high level of irritability and lack of endurance in communication; 
2) a direct proportional relationship between the scale of "reduction of personal achievements" and emotional stability $(\mathrm{r}=-0.445$ at $\mathrm{p}<0.01)$, selfcontrol $(r=-0.397$ at $p<0.05)$ and courage $(r=-0.380$ at $p<0.05)$, which is a vivid indication that the police sometimes experience professional incompetence, they are prone to mood instability and almost complete lack of control over their psycho-emotional state.

The results of the correlation analysis show that the police officers living with the "emotional burnout" syndrome show such individual and personality traits as: constant internal tension, fear in making independent decisions, low self-control and emotional instability.

The groups of respondents also carried out a comparative analysis according to Student's T-criterion, the main criterion of which is the period of service (see Table 1). It is clear that over the years (and hence, with the experience gained, or with adaptation or admission), all the indicators of emotional burnout somewhat decrease, demonstrating a decrease in the level of tension, resistibility and exhaustion.

Table 1

Average value and standard deviation of phases of emotional burnout by V. Boiko

\begin{tabular}{|c|c|c|c|c|c|c|}
\hline \multirow{2}{*}{ Period of service } & \multicolumn{2}{|c|}{ Tension } & \multicolumn{2}{c|}{ Resistance } & \multicolumn{2}{c|}{ Exhaustion } \\
\cline { 2 - 7 } & $\begin{array}{c}\text { average } \\
\text { value }\end{array}$ & deviation & $\begin{array}{c}\text { average } \\
\text { value }\end{array}$ & deviation & $\begin{array}{c}\text { average } \\
\text { value }\end{array}$ & deviation \\
\hline $\begin{array}{c}\text { group № 1 } \\
\text { (period of service - } \\
\text { until 3 years) }\end{array}$ & 34,2 & $\pm 22,4$ & 48,3 & $\pm 17,6$ & 31,4 & $\pm 18,0$ \\
\hline $\begin{array}{c}\text { group № 2 } \\
\text { (period of service } \\
\text { from 4 to 5 years) }\end{array}$ & 24,9 & $\pm 21,6$ & 43,6 & $\pm 16,2$ & 24,6 & $\pm 12,0$ \\
\hline
\end{tabular}

In the process of comparative analysis according to the method of "Diagnostics of the level of emotional burnout" (V. Boiko), it was revealed that in two groups of studied respondents the phase of exhaustion is not formed, although in group № 1 there are tendencies for its formation. The second component - the "phase of resistance" - is in the formation stage in both groups. In addition, all three phases are more expressed in group № 1 . In our opinion, this is due to the fact that this category of respondents is at the stage of adaptation to the new conditions of professional activity of lawenforcers, and they still do not feel (and therefore do not perceive) changes in their psychological and emotional states. 
To determine the relationship between individual characteristics and signs of emotional burnout, a factor analysis was used. According to the manifestation of these signs, the types of emotional burnout among the employees of the National Police are distinguished. Three factors have been identified, the cumulative set of which is over $63 \%$ (see Tables 2-4).

Table 2

Factor 1 "Anxiety-Exhausted Type"

\begin{tabular}{|c|c|c|c|c|c|c|c|}
\hline \multicolumn{8}{|c|}{ Factor 1} \\
\hline \multicolumn{8}{|c|}{ Anxiety-Exhausted Type } \\
\hline $\begin{array}{l}\frac{0}{\tilde{J}} \\
\text { n }\end{array}$ & 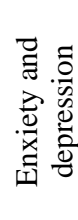 & 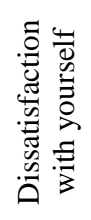 & 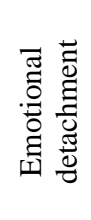 & 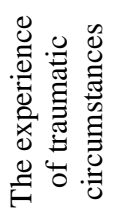 & 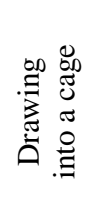 & 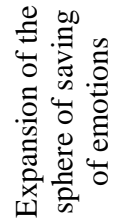 & 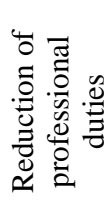 \\
\hline $\begin{array}{l}\text { received } \\
\text { indicator }\end{array}$ & 0,822 & 0,797 & 0,765 & 0,721 & 0,656 & 0,652 & 0,587 \\
\hline \multicolumn{2}{|c|}{ Weight } & \multicolumn{6}{|c|}{$\frac{1}{5,2712}$} \\
\hline \multicolumn{2}{|c|}{$\%$ of dispersion } & \multicolumn{6}{|c|}{43,921} \\
\hline \multicolumn{2}{|c|}{ Cumulative $\%$} & \multicolumn{6}{|c|}{43,921} \\
\hline
\end{tabular}

According to the results of the study, it can be argued that this type of police officers is characterized by highly expressed anxiety-depressive symptoms, caused by the risky and stressful nature of their professional activities. Work under the influence of stress factors causes a sense of constant tension, dissatisfaction with their actions and professional knowledge, and sometimes even an awareness of the falsity of the chosen sphere of activity. The state of dissatisfaction causes a significant level of stress, which leads to a weakening of the general tone, a decrease in the level of psycho-emotional state.

Table 3

Interpretation of Factor 2 "Morally Disorientated Type"

\begin{tabular}{|c|c|c|c|c|}
\hline \multicolumn{5}{|c|}{ Factor 2} \\
\hline \multicolumn{5}{|c|}{ Morally Disorientated Type } \\
\hline $\begin{array}{l}\frac{U}{\tilde{U}} \\
\tilde{n}\end{array}$ & 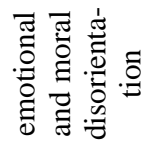 & 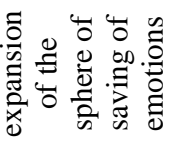 & 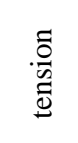 & 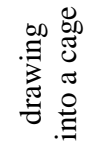 \\
\hline received indicator & 0,777 & $-0,534$ & 0,325 & $-0,300$ \\
\hline Weight & \multicolumn{4}{|c|}{1,189} \\
\hline$\%$ of dispersion & \multicolumn{4}{|c|}{9,910} \\
\hline Cumulative \% & \multicolumn{4}{|c|}{53,832} \\
\hline
\end{tabular}


Factor 2 - "morally-disorientated type" - demonstrates a 10 per cent dispersion indicator, showing the presence of the signs of personality disorientation and moral defects. Thus, the emotional and moral defect in this category of workers explains why it is extremely difficult for them to communicate in the field of professional activity, since they relate to the moral virtues of another person with distrust or caution. The moral disorientation among this category of respondents is caused by the following determinants: the lack of ability to distinguish between good and bad, to recognize the benefits and harm in the actions of citizens. The combination of moral defect and moral disorientation actually causes the formation of a syndrome of "emotional burnout," which, in turn, is manifested in the indifference towards the fate of objects of professional activity and apathy to fulfill their direct professional duties. Therefore, during their professional activity, they experience a certain emotional exhaustion and constant tiredness.

Table 4

Factor 3 "Emotionally-Selective Type"

\begin{tabular}{|c|c|c|}
\hline \multicolumn{3}{|c|}{ Factor 3 } \\
\hline Ecale & $\begin{array}{c}\text { Inadequalle selective } \\
\text { emotional response }\end{array}$ & Resistance \\
\hline $\begin{array}{c}\text { Received } \\
\text { indicator }\end{array}$ & 0,784 & 0,519 \\
\hline Weight & \multicolumn{2}{|c|}{1,087} \\
\hline$\%$ of dispersion & 9,056 \\
\hline Cumulative \% & \multicolumn{2}{|c|}{62,888} \\
\hline
\end{tabular}

The third factor - "emotionally-selective type" - found 9,1\% of dispersion among respondents. This category of respondents is characterized by inadequate understatement of the manifestation of emotional states and the lack of desire to establish emotional contact with the objects of professional activity. The oppression of the manifestation of emotional attitude to the working situations leads to significant emotional exhaustion, the dynamic development of psycho-emotional protection, and then - isolation. The formation of emotional closure leads to severe fatigue, the policeman becomes indifferent and outsider, which eventually may develop into cynicism and a demonstration of the pattern of action.

In a situation where the emotional burnout of police officers is a widespread phenomenon, work on its prevention and overcoming should have its own strategy, which involves targeting the tasks set; taking into account really existing processes and contradictions in social life that contribute to the 
existence of this phenomenon; definition of the main directions of prevention and counteraction of emotional burnout of workers; the formulation of goals, methods and means of this activity. The comprehensive prevention of emotional burnout by the National Police employees of Ukraine should include a number of measures designed to improve: the organization of professional psychological training of employees in order to increase motivation for effective service activities; legal regulation of professional activity; taking organizational and managerial measures.

In scientific researches devoted to problems of emotional burnout and prevention of its development, emphasis is placed on the implementation of preventive and precautious measures. Thus, I. Freudenberger, O. Skovholt note that the more the emotional exhaustion develops, the greater part of the personality and its life it is striking ${ }^{20,21}$. A study by J. Coster, R. Norcross, B. Farber motivates the need to prevent emotional burnout, since it is the best way to counteract it, rather than treat $\mathrm{it}^{22}$. The findings of $\mathrm{J}$. Coster, R. Norcross, B. Farber's research are supported by the scientific findings of researches regarding the ability to permanently eliminate the employee's emotional burnout, although W. Paine, B. Farber, L. Kytayev-Smyk note that it is impossible to cure emotional burnout in general $^{23}$. N. Pokrovsky, studying the foreign experience of psychological support for police officers, notes that "... the extreme nature of the activities of police services inevitably generates a significant amount of psycho-traumatic reactions among police officers. Therefore, three basic components of the post-traumatic support program are proposed: prevention, which mainly includes measures to ensure adequate selection of employees, their education, stress inoculation, as well as professional psychological training, psychological support in the subunits in extreme conditions and rehabilitation - post-crisis intervention and correction of consequences of mental trauma" 24 .

The majority of foreign countries have developed a strategy of psychological support for police officers, aimed at creating the best conditions for police fulfillment of operative and service duties. Thus, in Germany, the

${ }^{20}$ Skovholt T.M. The resilient practitioner: Burnout prevention and self-care strategies for counselors, therapists, teachers, and health professionals. Boston : Allyn \& Bacon, 2001. 286.

${ }^{21}$ Freudenberger H. Burnout: The high cost of high achievement. New York : Anchor, Doubleday, 1980. 240.

${ }^{22}$ Shift work and sleep: the Buffalo Police health study / Luenda E. Charles, Cecil M. Burchfiel, Desta Fekedulegn et al. // Policing: An International Journal of Police Strategies \& Management. 2007.Vol. 30, Issue 2. Pp. 215-227.

${ }^{23}$ Aldwin C.M. Stress, coping, and development, Second Edition: An Integrative Perspective. New York: Guilford, 2007. 432 p.

${ }^{24}$ Покровский Н.В. Организация психологической поддержки персонала полиции за рубежом. Режим доступу https://psyinst.moscow/biblioteka/part=articleid=1734 
Central Psychological Police Services, which carry out a number of psychological support measures for the activities of policemen designed to mitigate the negative impact of professional work on the psyche and health of police officers, have been founded and successfully operate; teaching methods of auto-training and psychological relaxation. In Spain, psychological support for policemen involves conducting psychological counseling and providing practical assistance to the police in case of professional complications; providing a full range of psychological services that are related to stress; conducting both individual and group consultations. During psychological support of the US police, much attention is being paid to the development of special psycho-preventive and psycho-correction programs. The main components of the program of psychological support of policemen are the formation of the concept of the phenomenon of emotional burnout; learning skills for non-violent communication and facilitation; development of selfregulation skills and autogenic training.

In the United Kingdom, during the psychological support of police officers, in addition to psycho-preventive and psycho-corrective measures, cognitive technologies aimed at the rational sphere of the personality of the police officer and emotional technologies, which are aimed at displacement, substitution and sublimation of negative emotions and painful feelings, are widely used.

According to the results of empirical research (factor analysis) three types of police are distinguished: "anxiety-exhausted type", "morally-disorientated type" and "emotionally-selective type". The anxiety-exhausted type is characterized by the dominance of anxiety and repression, the factors of which are stressful and risky professional activities, sometimes it can even lead to frustration with the profession.

Morally-disorientated type is characterized by the presence of moral defects and a certain level of disorientation of the individual, which is manifested in the inability to adequately assess the moral and ethical features of other individuals, respectively, accompanied by indifference and apathy to perform their professional duties. Some alienation in the performance of professional duties generates fatigue and exhaustion.

Emotionally-selective type is characterized by a decrease in emotional response, as well as emotional detachment from professional significant situations. Such workers are characterized by the closeness and active formation of the system of psychological protection. As a result, such a policeman feels constant fatigue, indifference and detachment in the performance of his professional duties.

In order to prevent the emotional burnout of employees of the National Police of Ukraine, practical psychologists of the Ministry of Internal Affairs 
of Ukraine carry out a series of measures that can be grouped into two large groups: 1) providing assistance at the organizational level; 2) providing assistance at the personal level. Thus, at the organizational level, practical psychologists of the Ministry of Internal Affairs of Ukraine carry out:

1) monitoring the capacity of the law enforcement team to identify persons who have signs of a syndrome of "emotional burnout";

2) development of correctional and preventive programs:

- "Pre-crisis prevention", aimed at accurate and effective prevention of possible adverse outcomes of the personal or professional crisis of the employee of the National Police of Ukraine;

- "Actual prevention", aimed at accurate and effective prevention of negative consequences of professional activity among employees of the National Police of Ukraine.

Assistance to employees of the National Police of Ukraine at the personal level is carried out through group and individual work. The group work involves conducting a training seminar in three directions: 1) informative and cognitive, which consists in conducting mini-lectures, the main task of which is the formation and development of knowledge on issues that reveal the essence, structure, levels and determinants of the syndrome of "emotional burnout"; 2) diagnostic, which allows law enforcement officers to master a set of diagnostic tools that allow to identify the presence of a syndrome of "emotional burnout"; 3) corrective-developing, is to apply the following forms of work, such as brainstorming ("brainstorming"), role-playing game, discussion, method of analysis and diagnostics of the situation; problematic (problem-searching) method; work in small groups; projective method. Individual prevention of the syndrome of "emotional burnout" is carried out in two stages, by analyzing: 1) the official situation; 2) their own emotional and physical condition.

The outlined model reflects a complete set of activities aimed at preventing and overcoming the "emotional burnout" syndrome among National Police staff of Ukraine. But, despite the fact that there is a system of measures aimed at preventing and overcoming the "emotional burnout" syndrome among the employees of the National Police of Ukraine, there is a need to improve preventive work in the units. Taking into account a huge experience of both Ukrainian and foreign scientists who studied the syndrome of "emotional burnout", as well as the urgent problems of practice, we consider it advisable to develop a unified system of preventive measures to overcome the "emotional burnout" syndrome among employees of the National Police of Ukraine. 


\section{CONCLUSIONS}

1. The concept of "emotional burnout of a policeman" is defined as the reproduction of a state of physical or psycho-emotional exhaustion by a police officer due to a long-term inclusion in a psychological trauma of moderate intensity.

2. The results of the empirical study suggest that the "emotional burnout" syndrome is not widespread among the questioned employees of the National Police of Ukraine because it is not formed due to various objective (for minor period of years) and subjective reasons (age physiological characteristics). It was established that the police officers, classified in the group № 1 (with seniority up to 3 years), fall into the risk zone of the syndrome of "emotional burnout".

3. The "emotional burnout" syndrome of the police officers, as confirmed by the respondents, is manifested through the domination of the component of "resistance" (as a kind of protective, although sometimes unconscious, reaction of the human body, manifested in inadequate, selective emotional response and can lead to emotional isolation, marginalization, indifference and cynicism).

4. Correlation analysis of the results of the empirical research has demonstrated the presence of statistically significant relations on the scale of methods, namely, between the indicators of emotional burnout (at different phases) and personal parameters: tension, closure, self-control, courage and emotional instability.

The applied methods of data processing of empirical research have given values to our scientific research in the context of distinguishing types of emotional burnout according to factor loadings, among which we can distinguish "anxiety-exhausted type", "morally-disorientated type" and "emotionally-selective type". Thus, we can characterize the peculiarities of the formation of emotional burnout among the staff of the National Police according to the presented type.

5. Taking into account the preliminary conclusions and the specifics and stressful features of the law enforcement activity, it is expedient to give the police opportunity for emotional recovery at the initial stages of their service. Otherwise, emotional exhaustion may become a professional deformation, and society may receive police terror instead of a high-quality and effective protection of law and order.

\section{SUMMARY}

The article is dedicated to the problem of the "emotional burnout" syndrome among the employees of the National Police of Ukraine. An overview of the basic scientific and theoretical foundations of the research, the most important 
of which is the justification of the content of the basic concepts of this phenomenon within the framework of psychological science, is given.

The analysis of the employees' of the National Police of Ukraine activities peculiarities and their influence on the occurrence of the "emotional burnout" syndrome symptoms is provided. It is noted that the specificity of the employees' of the National Police of Ukraine activities differs in that it contains a large number of situations with high emotional saturation and the cognitive complexity of interpersonal communication, and this, in turn, requires a significant contribution from the policemen to establish trusting relationships and the ability to manage the emotional tension of business communication in the field of their professional activity. It is revealed that special conditions of the employees' of the National Police of Ukraine professional activity, namely: the risk-taking nature of activities with unpredictable consequences (wounds, injuries), communication with antisocial elements, permanent mental and physical overload, often lead to mental activity deviation of a policeman, occurrence of post-traumatic disorders, propensity to deviant behavior and professional deformation, increased conflicts, aggressiveness, etc.

It has been revealed that the general feature and cause of the "emotional burnout" syndrome of the employees of the National Police of Ukraine is the presence of an internal conflict among the requirements of the Ministry of Internal Affairs of Ukraine, the attractiveness of working there, expectations and real possibilities of a policeman. It has been defined that the syndrome of "emotional burnout" is: the reaction of a policeman's organism and psychological sphere, which arises as a result of prolonged exposure to stresses of medium intensity, caused by his professional activity; the result of an unmanageable long-term stress; a mental state characterized by the emergence of emotional emptiness and fatigue caused by professional activity, and combines emotional emptiness, depersonalization and reduction of professional achievements; a type and precondition of professional deformation of a person.

\section{REFERENCES}

1. Юридико-психологічні засади запобігання професійній деформації працівників правоохоронних органів. Львів: ЛьвДУВС, 2016. 847 с.

2. Юридична психологія: особистісно-діяльнісний підхід. К.: Слово, 2017. $405 \mathrm{c}$.

3. Орел В.Е. Исследование феномена психического выгорания в отечественной и зарубежной психологии // Проблемы общей и организационной психологии. Ярославль, 1999. С. 76-97.

4. Бойко В.В. Синдром “эмоционального выгорания" в профессиональном общении. 2-е изд. СПб.: Сударыня, 2001. 434 с. 
5. Технології роботи організаційних психологів / За наук. ред. Л.М. Карамушки. К.: Фірма "ІНКОС", 2005. 366 с.

6. Maslach, C., Goldberg, J. Prevention of burnout: New perspectives // Applied and Preventive Psychology, 1998, V. 7, pp. 63-74.

7. Schaufeli, W.B., Salanova, M., Gonzalez-Roma, V. and Bakker, A.B. The measurement of engagement and burnout and A confirmative analytic approach // Journal of Happiness Studies, 2003, V. 3, pp. 71-92.

8. Бойко В.В. Синдром "эмоционального выгорания" в профессиональном общении. - 2-е изд. - СПб.: Сударыня, 2001. - 434 с.

9. Maslach C.M. Job burnout: new directions in research and intervention // Current Directions in Psychological Science, 2003, V. 12, pp. 189-192.

10. Burke, R.J., Greengalass, E. A longitudinal study of psychological burnout in teachers // Human Relations, 2003, V. 48 (2), pp. 187-202.

11. Maslach, C., Leiter, M.P. The truth about burnout: How organization cause personal stress and what do about it. San Francisco, CA: Jossey-Bass, 1997. $197 \mathrm{p}$.

12. Форманюк Т.В. Синдром “эмоционального сгорания” как показатель профессиональной дезадаптации учителя // Вопросы психологии. 1994. № 6. C. 57-63.

13. Водопьянова Н.Е., Старченкова Е.С. Синдром выгорания: диагностика и профилактика. 2-е изд. СПб.: Питер, 2008. 336 с.

14. Maslach, C., Schaufeli, W.B., Leiter, M.P. Job Burnout // II Annual Review of Psychology, 2001, V. 52, pp. 397422.

15. Seligman, M., Csikszentmihalyi, M. Positive Psychology: An introduction // American Psychologist, 2014, V. 55, pp. 5-14.

16. Kurtz, D. Burnout Among Police Officers: Differences In How Male, Female Police Officers Manage Stress May Accentuate Stress On The Job // American J. of Criminal Justice, 2008, V. 2, pp. 17-26.

17. Свон Р. Д. Эффективность правоохранительной деятельности и ее кадровое обеспечение в США и России. СПб. : Алетейя, 2000. 296 с.

18. Покровский Н.В. Организация психологической поддержки персонала полиции за рубежом. Режим доступу https://psyinst.moscow/ biblioteka/part=articleid $=1734$

19. Литвинова Г.А. Социально-психологическое обеспечение деятельности полиции Баварии (Германия) // Юридическая психология. 2010. № 3. C. 32-36.

20. Skovholt T.M. The resilient practitioner: Burnout prevention and selfcare strategies for counselors, therapists, teachers, and health professionals. Boston : Allyn \& Bacon, 2001. 286. 
21. Freudenberger H. Burnout: The high cost of high achievement. New York : Anchor, Doubleday, 1980. 240.

22. Shift work and sleep: the Buffalo Police health study / Luenda E. Charles, Cecil M. Burchfiel, Desta Fekedulegn et al. // Policing: An International Journal of Police Strategies \& Management. 2007. Vol. 30, Issue 2. Pp. 215-227.

23. Aldwin C. M. Stress, coping, and development, Second Edition: An Integrative Perspective. New York : Guilford, 2007. 432 p.

24. Покровский Н.В. Организация психологической поддержки персонала полиции за рубежом. [Електронний ресурс]: режим доступу https://psyinst.moscow/biblioteka/part=articleid=1734

Information about the author:

Kisil Z. R.,

Doctor of Law Sciences, Professor, Academician of the HEAS of Ukraine, Dean of Faculty No. 7, Lviv State University of Internal Affairs 